August 2007

\title{
International Humanitarian Law and Interventions-Rwanda, 1994
}

Elizabeth More

Follow this and additional works at: https://scholarcommons.usf.edu/gsp

\section{Recommended Citation}

More, Elizabeth (2007) "International Humanitarian Law and Interventions-Rwanda, 1994," Genocide Studies and Prevention: An International Journal: Vol. 2: Iss. 2: Article 5.

Available at: https://scholarcommons.usf.edu/gsp/vol2/iss2/5

This Article is brought to you for free and open access by the Open Access Journals at Scholar Commons. It has been accepted for inclusion in Genocide Studies and Prevention: An International Journal by an authorized editor of Scholar Commons. For more information, please contact scholarcommons@usf.edu. 


\title{
International Humanitarian Law and Interventions-Rwanda, 1994
}

\author{
Elizabeth More \\ Macquarie University, New South Wales, Australia
}

International humanitarian law (IHL) applies to armed conflicts between and within states. It focuses on constraining the parties involved in such conflict to minimize human suffering, both of combatants and civilians, and, in so doing, is complemented by international human-rights law (IHRL). Recent events show the difficulties in implementing and enforcing both IHL and IHRL, and debate has escalated on whether or not such laws provide any basis for intervention, including, most controversially, military intervention.

This article reinforces earlier arguments that the 1994 Rwandan genocide demonstrates a failure to uphold both IHL and IHRL in the face of genocide and ongoing massive human-rights abuses. Certainly we can blame the United States and the United Nations (especially its Security Council), but blame also attaches to those states that failed in the will and commitment to resolve the tragedy by meaningful international action using the legal justifications available. Their indifference suggests complicity in the final tragedy-almost a million Rwandans died, and some further three million became refugees-and points to the need to reassess IHL and IHRL theory and practice. Positive alterations in human-rights norms and growing challenges to traditional notions of sovereignty result in the notion that sins of omission, such as occurred in Rwanda in 1994, are actually worse than sins of commission. Moreover, it is timely to explore this failure again, given the belated legal recognition of the Rwandan genocide by the International Criminal Tribunal for Rwanda (ICTR) in 2006 and the ongoing crisis in the Darfur region of Sudan.

\section{Introduction}

\begin{abstract}
Unfortunately, there remains a very wide discrepancy between the scale of abuses being perpetrated in situations of internal armed conflict, and the underlying promise of IHRL and IHL standards. ${ }^{1}$

The principle of non-intervention denies victims of tyranny and anarchy the possibility of appealing to people other than their tormentors. It condemns them to fight unaided or die. Rescuing others will always be onerous, but if we deny the moral duty and legal right to do so, we deny not only the centrality of justice in political affairs, but also the common humanity that binds us all. ${ }^{2}$
\end{abstract}

International humanitarian law (IHL) aims to protect combatants, civilians, and victims in armed conflict situations, both between and within states. It tries to prevent and punish breaches, and so devises specific rights and responsibilities for both states and individuals, in its efforts to "humanize" war. ${ }^{3}$ In situations of war or emergency, IHL and international human-rights law (IHRL) work together from different perspectives to protect individuals and clearly define what is permissible.

Elizabeth More, "International Humanitarian Law and Interventions-Rwanda, 1994." Genocide Studies and Prevention 2, 2 (August 2007): 155-172. (C) 2007 Genocide Studies and Prevention. doi: 10.3138/gsp/004 
The distinction between these two complementary areas of law can be summarized as follows:

\begin{abstract}
Humanitarian law applies in situations of armed conflict... whereas human rights, or at least some of them, protect the individual at all times, in war and peace alike. However, some human rights treaties permit governments to derogate from certain rights in situations of public emergency. No derogations are permitted under IHL because it was conceived for emergency situations, namely armed conflict.

Humanitarian law aims to protect people who do not or are no longer taking part in hostilities. The rules embodied in IHL impose duties on all parties to a conflict. Human rights, being tailored primarily for peacetime, apply to everyone. Their principal goal is to protect individuals from arbitrary behaviour by their own governments. Human rights law does not deal with the conduct of hostilities. ${ }^{4}$
\end{abstract}

The two major universal instruments used are the Universal Declaration of Human Rights and the Convention on the Prevention and Punishment of the Crime of Genocide (UNCG), both dating to $1948 .^{5}$ Yet political, economic, social, and ideological differences can combine to militate against compliance, and state sovereignty enhances contravention.

Over the last decade or so, we have seen the traditional practice of such laws increasingly challenged, demonstrating the global impact of intra-state conflicts and the difficulty of turning legal rhetoric into reality. ${ }^{6}$ One such challenge arose in Rwanda in 1994.

Among strategies for humanitarian intervention, military coercive action to protect those at risk remains controversial, with ongoing debates about the right to intervene, how and when such a right should be exercised, and whose authority is to be used. The case of Rwanda is controversial because such external military intervention was not forthcoming to protect a sovereign state's citizens when that state had failed in its responsibility to protect them from avoidable catastrophe. ${ }^{7}$

\title{
Legal Foundations
}

IHL governs traditional humanitarianism and extends it into the political arena through constraints on the conduct of warfare. ${ }^{8}$ The laws of war are complemented by other legal frameworks, including those relating to crimes against humanity, genocide, human rights, and torture. ${ }^{9}$ The Charter of the United Nations governs the use of armed force within the international community as its major international convention. ${ }^{10}$

While there is general agreement that international law cannot sanction or ignore atrocities, debate centers on the need for a further legal basis for states' intervening in such situations. This debate includes concern about adopting a false dichotomy between just war and just peace, with some arguing that intervention is morally but not legally valid, and about whether ends justify means. On the one hand are arguments that the UN Charter, particularly articles 2(4) and 2(7), ${ }^{11}$ together with customary international law, does not provide a "right" of humanitarian intervention. On the other hand is a growing tolerance for some activities regarded as humanitarian intervention and legal arguments interpreting chapter 7 of the UN Charter as permitting legal sanction of military intervention in the face of major human-rights abuses. $^{12}$

As well as chapter 7 and the human-rights provision of the UN Charter, human protection through military intervention is broadly approved by the Geneva Conventions and Additional Protocols on IHL, as well as by principles of natural law 
and by the Rome Statute of the International Criminal Court (ICC). ${ }^{13}$ These regulate multilateral action and are the basis for the legality and legitimacy of humanitarian intervention. Such intervention can be unilateral action based on self-defense; multilateral action based on chapter 7 (where there are threats to international peace and security); or Security Council-authorized action (covering political instability). ${ }^{14}$

Conditions for interventions based on human protection under IHL/IHRL include the following:

- Actions defined by the framework of the UNCG

- The threat or occurrence of large-scale loss of life

- Different manifestations of "ethnic cleansing"

- Crimes against humanity and violations of the laws of war

- Situations of state collapse

- Overwhelming natural or environmental catastrophes ${ }^{15}$

Particularly relevant to the situation in Rwanda is the 1948 UNCG. This convention proscribes acts with specific intent to completely or partially destroy a national, ethnic, racial, or religious group. The UNCG and the Security Council's 1994 Report of the Secretary General on Rwanda formed the mandate for the establishment of the International Criminal Tribunal for Rwanda (ICTR) in $1994 .{ }^{16}$ Given that the UNCG includes prevention and the presumed obligation to intervene, the international community's lack of will in the face of mounting evidence over a number of years seems tragic. $^{17}$

In any effort to turn legal rhetoric into reality, action is constrained by numerous variables connected with perceptions of statehood and sovereignty. Moreover, there can be a disjunction, as the Independent International Commission on Kosovo found, between the law and the ethics of intervention: there, intervention was illegal but legitimate. ${ }^{18}$

Humanitarian assistance, in preventing and alleviating human suffering and providing humanitarian relief to civilians, is supposed to uphold the principles of humanity, impartiality, and neutrality. ${ }^{19}$ Legal, moral, political, organizational, and cultural problems abound, however, including concerns that interventions may create their own human-rights problems. ${ }^{20}$

Defining humanitarian intervention is itself fraught with difficulties. Some ${ }^{21}$ adopt a broad definition, distinguishing between coercive and non-coercive or forcible and non-forcible means and between the use of military force and that of civilian humanitarian agencies. However, the classical definition focuses on stopping major abuses of human rights through the use of international military force within a state. Adopting the latter definition raises problems of international justice and order, interveners' risks relating to casualties and resources, and the potential for failure. ${ }^{22}$

Moreover, diverse approaches to intervention create confusion. Solidarist views of the moral and legal universalism of intervention stress inalienable and globally equitable human rights; realist views, pursued by many politicians, are based on decisions of national interest and power/politics; and pluralist views, denying the existence of universal basic human rights, emphasize cultural relativism and question the effectiveness of humanitarian intervention. ${ }^{23}$

Aside from these debates, a central challenge is defining state sovereignty, premised on the international community's not interfering in a state's internal armed conflicts. Intervention is permissible through (a) chapter 7 and arts. 2(7) and 25 of the 
UN Charter, given threats to international peace and security; (b) the Universal Declaration of Human Rights; and (c) art. 7 of the Rome Statute and the UNCG, concerned with crimes against humanity and genocide. ${ }^{24}$

\section{Rwanda ${ }^{25}$}

There was little innocence in Rwanda-historically, those in power subjugated others, and both the Hutu and Tutsi engaged in violence. The role of racist ideology in contributing to the genocide is contested. Some claim that the genocide was the responsibility of the Hutu alone, intent on exterminating the Tutsi ethnic group in a premeditated and systematic way, while others dispute this argument. ${ }^{26}$ No one, however, doubts that the Rwandan genocide of 100 days (April-July 1994) is one of the major test cases for IHL and IHRL.

The roots of the tragedy lay in colonization. Indeed, it may be that the roots go back at least as far as 1959, when massacres against the Tutsis began to take place every few years. That year saw the first mass exodus of Tutsis out of Rwanda.

The genocide itself, however, had two phases:

- Phase 1: the civil war (1 October 1990-6 April 1994)

- Phase 2: genocide and its aftermath (6 April-15 July 1994, and 15 July-end of 1994)

In Phase 1, a UN peacekeeping force, the United Nations Assistance Mission for Rwanda (UNAMIR I), supported a diplomatic and ostensibly democratic process of decision making set out in the Arusha agreement. ${ }^{27}$ With the massacre as "a threat to peace," no humanitarian intervention to end genocide occurred until late June, when the UN endorsed the French-led military Operation Turquoise. UNAMIR II was deployed after the genocide was stopped by the Rwandan Patriotic Front (RPF) in July 1994. What was unique about this genocide was the massive involvement of civilians in carrying out the massacres; the brutality of its processes; its multiple targets; the killing of Hutu by Hutu for political and social reasons; and the genocidal killing by civilian Hutu mobs of Tutsi civilians. ${ }^{28}$

The UN, the Organization of African Unity (OAU), and other global agencies were aware of the earlier instability that laid the foundations for this catastrophe. Warnings were issued as a result of human-rights investigations (e.g., the UN report compiled by Bacre Waly Ndiaye, special rapporteur on executions, warning of the risk of genocide and suggesting some preventive measures ${ }^{29}$ ), alongside efforts at preventing the tragedy through diplomacy and using UN peacekeeping forces. ${ }^{30}$ Even without recourse to Rwanda's earlier history, signs of escalating problems were clear from 1990 onwards-when the RPF entered Rwanda in 1990; in the troubled discussions leading to the Arusha peace agreement in 1993; in the increasing racist media propaganda (including tactics of dehumanization); in the rise of extremist Hutus; and in the coordinated campaign of arms and hatred toward a final solution-the annihilation of Tutsis to preserve Hutu privilege and power. ${ }^{31}$ Such problems, coupled with difficult social, political, and economic conditions (including a famine), were the basis for mass murder. With the 1994 plane crash that killed the presidents of both Rwanda and Burundi, violence flared, beginning the genocide of 800,000 Rwandans, mainly Tutsi and moderate Hutu. The massacre ended with the RPF victory in July $1994 .^{32}$

The evidence is that the global community, armed with both IHL and IHRL, failed to react adequately to the genocide. 


\section{Key Issues Concerning IHL in the Conflict}

The majority of the conditions allowing for an intervention based on human-protection law were evident in Rwanda, especially from 1990 onwards. The humanitarian intervention that took place in response consisted of unarmed and pacific actions in preventative diplomacy; the Arusha process, which was unsuccessful in introducing democracy; the armed and pacific actions with peacekeeping of UNAMIR I and II, the United Nations Observer Mission Uganda-Rwanda (UNOMUR), and Operation Turquoise; post-genocide assistance to refugees; and the Rwandan tribunal. There was little effective action, military or otherwise, to prevent the catastrophe, and when action was taken, it failed. Rwanda and international humanitarian law had lost. ${ }^{33}$

There was nevertheless potential for successes in the turmoil, even though some did not eventuate. These included some aspects of the unimplemented Arusha agreement process and documentation that, if successfully implemented, could have led to the end of the civil war and the establishment of a democracy; Operation Turquoise, a humanitarian effort that did too little and came too late-successful in saving around 15,000 lives, but failing by offering safe conduct for some génocidaires; and the refugee camps, which succeeded in providing some respite to refugees but which also failed by providing safe haven for many génocidaires. And success was evident in a number of war criminals being brought to trial, through a slow process, though unfortunately many still escaped justice. ${ }^{34}$

The Report of the Independent Inquiry into the Actions of the UN during the1994 Genocide in Rwanda cites the key problem as

a lack of resources and a lack of will to take on the commitment which would have been necessary to prevent or to stop the genocide. UNAMIR, the main component of the United Nations presence in Rwanda, was not planned, dimensioned, deployed or instructed in a way which provided for a proactive and assertive role in dealing with a peace process in serious trouble. ${ }^{35}$

Its detailing of deficiencies is harrowing and troubling, especially given the ongoing crisis in Darfur. ${ }^{36}$

The major obstacle to developing intervention in Rwanda was that

humanitarian intervention and enforcement of the Genocide Convention became prime moral concerns, but legal constructs and supportive machinery for the new international order were not yet sufficiently developed. Rwanda therefore demonstrated the fateful gap between intent and results, between principles and performance. $^{37}$

Others ostensibly were ${ }^{38}$

- Increasing caution based on prior intervention history ${ }^{39}$

- Political and domestic issues, including the potential for loss of troops

- The dysfunctional bureaucracy at the UN, characterized by a lack of coordination, bureaucratic indifference, and an inflexible mindset

- Humanitarian concerns coming second best to base institutional interests

- Lack of interest on the part of the Security Council

- The UN's dependence on member states to supply troops for military intervention

- Poorly trained troops

- The lack of a clear humanitarian intervention mandate capable of incremental adjustment to meet changing needs 
- Overt international indifference (including media coverage) and inadequate resources for intervention (e.g., supporting the residual UNAMIR troops), which communicated poor resolve and a lack of intent to act

- An inability to handle multiple crises, with competing foreign-policy concerns during the genocide involving China, North Korea, Croatia, Haiti, and Angola

- The possibility of an inherently racist international humanitarian order

Moreover, US President Bill Clinton's Policy Decision Directive 25 (3 May 1994) advocated a very cautious approach to peacekeeping, expressing concern about resource implications. ${ }^{40}$ This contextualized the Security Council's caution, its emphasis on a cease-fire with its peacekeeping force, and member states' unwillingness to provide resources while already engaged elsewhere. ${ }^{41}$

Given IHL, IHRL, and the UNCG, the Security Council's unanimous vote on 21 April 1994 to reduce UNAMIR forces, in the face of evidence of genocide, is staggering! So too is its failure to respond to Kofi Annan's letter of 29 April 1994, which urged the UN to move from neutral mediation to ending the civilian massacres. ${ }^{42}$

More successful was the cable sent from Rwanda on 6 May 1994 by UN Special Representative Jacques-Roger Booh-Booh, ${ }^{43}$ reporting on the civilian massacres and the worsening situation and asking that UNAMIR be given the resources and the mandate to end the killings and continue efforts for a cease-fire. This cable provided a basis for ongoing discussions by the Security Council during the month of May, leading to establishment of UNAMIR II (17 May 1994) and an expansion of the mission's troops to 5,500. This was aided by a report to the Security Council (31 May 1994) that offered further evidence of genocide, including evidence collected since January and not acted upon. Only in late May 1994 did the Security Council act more appropriately, imposing an arms embargo and expanding UNAMIR's mandate to provide civilian, refugee, and humanitarian operations security. In June it finally authorized a French operation to protect refugees because Rwanda had become a threat to regional peace and security. ${ }^{44}$ However, by 25 July only 550 troops had been committed, highlighting the ongoing lack of UN member engagement. ${ }^{45}$

The final failure was that, after the genocide, the catastrophe spilled over more broadly into the African Great Lakes crisis. ${ }^{46}$

Elsewhere, the situation was different. For example, Serbian sovereignty was confronted by the NATO attack on Kosovo, which challenged international law by breaching two fundamental provisions of the UN Charter (arts. 2(4) and 2(7)). The basis of the NATO action was a moral justification on grounds of humanitarian necessity. This action provides an opportunity for establishing customary international law, with retrospective justification for intervening against a state that had clearly committed crimes against humanity. Cases such as Rwanda's challenge international law, showing the need for intervention on a humanitarian basis without UN approval, demonstrating what can happen when Security Council politics result in partisanship and unforgivable delay while thousands are slaughtered. In Rwanda, the peacekeeping interventions did not mitigate suffering. ${ }^{47}$

What confronts us is the failure to act, even when action is supported by law. ${ }^{48}$ Consequently, the genocide in Rwanda serves to remind us of the difference between human aspirations (enshrined in law, morality, and ethics) and the reality of inaction. The international community was unwilling to intervene to save Rwandan lives, even with its imperfect legal tools. ${ }^{49}$ 
The problem of terminology also emerges, not only in the fuzziness of the UNAMIR mandate but, particularly, in the reluctance to use the term "genocide." 50 Given the information provided by NGOs in 1993 and early 1994, as well as reports from the UN's own representatives in 1994, it is apparent that problems with politics, morality, and imagination, rather than inadequate warnings, prevented an early response to the unfolding genocide. Yet, clearly, genocide was evident in April, alongside killings related to the civil war and those politically or socially motivated. ${ }^{51}$

\section{Lessons}

Genocide stands to crimes against humanity as premeditated murder stands to intentional homicide... The sad reality is that, five years after the Rwandan genocide, and despite professions of guilt about their inertia while the crimes were taking place, States are hardly more prepared today to intervene to prevent genocide in central Africa. $^{52}$

While the UNCG imposes a moral obligation on states to prevent and punish genocide, this does not mean-contrary to what policy makers imagined in 1994-immediate deployment of military forces; rather, responses may include military as well as diplomatic, juridical, and economic actions. So what is required by law, morality, and ethics needs clarification. ${ }^{53}$

The UNCG is concerned with both preventing and punishing the crime of genocide, and, while the two are intimately connected, in the deterrent function of law, punishment is often the aspect most emphasized. Certainly the convention does not cover preventative measures in relation to hate propaganda, racist organizations, or preparatory acts potentially leading to genocide. And, indeed, there is an ongoing debate about humanitarian intervention per se. These issues certainly were evident, as outlined earlier, in the failure to prevent the Rwandan genocide, and especially in the conduct of the UN and its constituent elements. President Clinton did, however, announce the establishment of a genocide early warning center, to be directed by the CIA and the State Department. Moreover, besides amending the UNCG so as to enhance the duty to prevent genocide, states could commit to using force to prevent genocide in a General Assembly resolution, and regional bodies (e.g., the OAU/African Union) could also adopt this approach. This would authenticate and make binding law the convention's obligation to prevent genocide, which could be further enhanced by extending the range of punishable acts to include, for example, the type of hate propaganda used to such effect in Rwanda, and by requiring states to report on their compliance with the UNCG. ${ }^{54}$

A major weakness demonstrated by the international community's reaction to the genocide in Rwanda is "its extreme inadequacy to respond urgently with prompt and decisive action to humanitarian crises entwined with armed conflict." Rwanda showed that, even with Security Council authorization of international action to resolve humanitarian suffering, as with UNAMIR II, there is no guarantee that effective action will occur. Unless the right administrative processes are in place, IHL/IHRL cannot be adequately implemented. "Rwanda in 1994 involved a failure, not only by key member states, but in the leadership of the UN and in the effective functioning of the Secretariat as well."56 It also revealed a "neutral humanitarianism," with UNAMIR as "a kind of hedged bet, in which intervening parties salve their consciences while avoiding the difficult political commitments that might actually stop civil war." 57 Unfortunately, IHL/IHRL's weaknesses, rather than their strengths, were revealed by the Rwandan tragedy. 
Simon Chesterman, in 2001, that claimed international law is devalued through the incoherence of the Security Council's mandate. ${ }^{58}$ Allen Buchanan agrees: "The perception is growing that the requirement of Security Council authorization is an obstacle to the protection of basic human rights in internal conflicts." 59 The Security Council's performance since Rwanda confirms such opinions. Buchanan argues that

[the intervention in] Kosovo and the ensuing debate over its justifiability have focused attention on the deficiency of existing international law concerning humanitarian intervention. In the aftermath... [there is] a widening consensus that there is an unacceptable gap between what international law allows and what morality requires. ${ }^{60}$

For him, this justifies illegal action as a basis for reforming international law. This may be especially true where, as in the Rwandan conflict, political concerns prevent appropriate intervention. Tobias Vogel writes that

The conflicts in Rwanda or Afghanistan or Sudan may be serious, but as long as no regional power feels threatened by them, the prospects of outside intervention are weak. This is morally indefensible and potentially subversive of the idea of general human standards enforced by individual states under multilateral authorization, and it clearly contravenes the legal obligation of governments in dealing with genocide. That these provisions are not taken seriously anyway is no reason to discard them altogether. ${ }^{61}$

Moreover, as Michael Innes warns, the future for humanitarian interventions looks bleak unless we can repackage human-rights considerations to appeal to both doves and hawks. Innes adds that, because states generally regard intervention as a right rather than an obligation (under the UNCG), genocide prevention founders on cynical policy decisions related to national interests. And in the absence of appropriate measures of censure or penalties for failing in a duty to intervene, political agendas and dysfunctional self-interest will prevail. Such interests are currently dominated by US military potency, and, consequently, a pragmatic process of selective engagement is likely to be standard. ${ }^{62}$

Recommendations from the Rwanda inquiry report ${ }^{63}$ suggest how the United Nations can improve its response to international humanitarian crises:

- Establish a UN Action Plan to prevent genocide

- Improve its capacity in peacekeeping, including resources

- Have the political will to act in cases of genocide or gross violations of human rights

- Improve its early warning capacity

- Introducing stronger measures to protect civilians in conflict situations

- Enhance security for UN and associated personnel

- Ensure full cooperation among officials responsible for the security of diverse UN personnel

- Improve information flow and communication within the UN system

- Improve the information flow to the Security Council

- Increase information on human-rights issues

- Coordinate national evacuation operations with UN missions on the ground

- Examine potential suspensions of member states from the Security Council in exceptional circumstances 
- Gain the support of the international community for rebuilding Rwandan society following the genocide

- Acknowledge the UN's share of responsibility in the failure to prevent or arrest the Rwandan genocide

John Clarke reaffirms this need for change, suggesting that reform of international humanitarian intervention focus on the norms and institutions shaping and regulating the process. ${ }^{64}$ Unfortunately, the Carlsson report has not really been acted upon, or, at least, most of the points listed have not been addressed. Even the position of special adviser on the prevention of genocide (established in 2004 with the appointment of Juan Méndez), is part time and underfunded. ${ }^{65}$

\section{Contemporary Efforts to Improve IHL}

In November 1994, the Security Council established, as part of the Hague Tribunal, the International Criminal Tribunal for Rwanda (ICTR), a court in Arusha mandated to hear cases relating to the Rwandan genocide. This advanced international law by providing for individual responsibility for breaching art. 3 of the 1949 Geneva Conventions, as well as punishment for genocide and crimes against humanity. Some initial problems, including corruption, gave way to a drawn-out process, with some prisoners still awaiting trial. ${ }^{66}$ It remains unclear to what extent such tribunals might act to deter future genocides, for

deterrence... is frequently elusive.... Prevention requires more than just taking steps
to deter individuals from committing crimes by prosecuting offenders, however.
Effective prevention over time also requires more far-reaching initiatives. These
include... overcoming a legacy of impunity by strengthening the rule of law, including
the institutions and cultural attitudes that help reinforce new norms of behavior and
new patterns of accountability; and addressing grievances and inequalities that
may underlie long-standing conflicts. 67

Moreover, "trials are not a panacea. They must be integrated into a broader program of social reconstruction." 68

The International Committee of the Red Cross (ICRC) admits that "international humanitarian law cannot serve as a basis for armed intervention in response to grave violations of its provisions: the use of force is governed by the United Nations Charter." Nevertheless, the ICRC promotes using the term "armed intervention in response to grave violations of human rights and of international humanitarian law," fully recognizing the controversy surrounding such intervention, whether by states, international organizations, or NGOs and understanding that, by growing customary law, the category of threats to peace can include intrastate violations of IHL/IHRL. ${ }^{69}$

The UN Charter is static in terms of its normative framework but is supposed to evolve through application to practical situations. As such, it and broader international law provide a basis for slowly bridging the gap between notions of justice and morality and what is strictly legal. ${ }^{70}$

Clarke also emphasizes change, suggesting that escalation in intrastate conflicts has created a new interventionist agenda, broader than traditional peacekeeping and incorporating multiple actors working interdependently. Accompanying this phenomenon are altered international norms, especially reinterpreting state sovereignty and making the legal threshold for action under chapter 7 much lower. Certainly, we are now better able to recognize that military humanitarian intervention must be part of a larger, overarching conflict agenda, involving not only early-warning and 
conflict-prevention processes but also post-conflict activities of development and reconstruction. ${ }^{71}$

In their report on intervention and sovereignty for Canada's International Development Research Centre, Gareth Evans and Mohamed Sahnoun emphasize a responsibility to protect rather than a right to intervene, arguing that we must have standards for intervening for human protection that are consistent, credible, and enforceable. The authors provide a useful summary of core principles for protection and military intervention, finding growing acceptance that

the responsibility to protect its people from killing and other grave harm [is] the most basic and fundamental of all the responsibilities that sovereignty imposes-and that if a state cannot or will not protect its people from such harm, then coercive intervention for human protection purposes, including ultimately military intervention, by others in the international community may be warranted in extreme cases. ${ }^{72}$

It is not clear how much attention the UN has paid to this advice.

K. Mills suggests that, given the failure to act and to act rapidly, some sort of standing rapid-action troop force might be a solution, or that it might be useful to have the option of regional collective action instead of UN action. If a sovereign government failed its people by, for example, committing gross violations of human rights, then it could be declared illegitimate and appropriate global action taken. Mills stresses that humanitarian intervention ought be regarded as police work and proposes that law enforcement, supported by specialist tribunals and the ICC, might deter breaches of IHL/IHRL. ${ }^{73}$

In 2004, the UN secretary-general proposed that the new post of special rapporteur be established, with the mandate to warn the Security Council of potential genocides and trigger appropriate UN interventions. ${ }^{74}$ As mentioned above, this position has been occupied by Juan Méndez since 2004, and much recent attention has been focused on Darfur. Méndez issued a special report in 2005 and continues to endorse the Genocide Intervention Network. ${ }^{75}$

More recently, the secretary-general urged UN members to accept major reforms, including enlarging the Security Council and implementing new guidelines for authorizing military action. This was a timely effort, as US Secretary of State Condoleezza Rice had recently warned that the UN would not survive unless it embraced desperately needed reform. ${ }^{76}$

In addition, recent debates over intervention have affected attitudes towards future situations such as those in Rwanda and Kosovo and enabled legitimate diplomatic discussion of intervention to protect victims of atrocities. ${ }^{77} \mathrm{~A}$ midpoint between rigid adherence to the text of the UN Charter and efforts to define criteria for a doctrine or right of humanitarian intervention seems to offer a way ahead. Nevertheless, the issue of adequate resources remains a vexing problem. ${ }^{78}$

Burleigh Wilkins argues for changing domestic and international law in subtle ways to deal with situations requiring humanitarian intervention to protect basic human rights. ${ }^{79}$ Indeed, the 2004 UN report A More Secure World states that while the Security Council can act preventively, this has rarely occurred and calls for a much more proactive approach in taking early decisive action. It also emphasizes that the UN Charter needs more clarity on intervening to stop mass atrocity; on protecting, not just reaffirming, fundamental human rights; and, especially, on implementing the UNCG. The report endorses

the emerging norm that there is a collective international responsibility to protect, exercisable by the Security Council authorizing military intervention as a last resort, 
in the event of genocide and other large-scale killing, ethnic cleansing or serious violations of international humanitarian law which sovereign Governments have proved powerless or unwilling to prevent. ${ }^{80}$

Others urge better research, from diverse perspectives, into the crimes of international humanitarian law, better understanding and preventing IHL/IHRL violations, and early-warning indicators. ${ }^{81}$

\section{Conclusion}

International refusal to recognize the genocide was wrong, both morally and legally. ${ }^{82}$

In spite of the record of increasing military humanitarian intervention over the last decade, the global community has not realized the principle of humanitarian equity in policy or action. ${ }^{83}$ Rwanda is a clear example of this, and we seem to have learned little, given the current genocide occurring in Darfur, which seems to confirm the possibility of racism in intervention. ${ }^{84}$ It seems to repeat the international community's apathy over the Rwandan disaster, although the United States has already declared the crisis a genocide. ${ }^{85}$ The UNCG explains how the international community ought to react, but adequate concern, action, and aid are again not forthcoming: again the international community is complicit in atrocities. ${ }^{86}$

In 1999, Kofi Annan, then secretary-general of the United Nations, acknowledged the failure to prevent or halt the Rwandan genocide in 1994, claiming that "of all my aims as Secretary-General, there is none to which I feel more deeply committed than that of enabling the United Nations never again to fail in protecting a civilian population from genocide or mass slaughter." 87 The crisis in Darfur reveals how little we seemed to have learned from the Rwandan genocide about using IHL/IHRL effectively in humanitarian intervention. Peter Beinart claims that "in hindsight, stopping genocide is easy. But in Darfur, where it is happening now, stopping genocide is brutally hard... Diplomacy hasn't stopped the genocide. It's time to give war a chance." $" 88$

Or, as Christopher Taylor writes,

we need to understand human malevolence in all of its ramifications, for it seems that otherwise we are doomed, as happened in Rwanda, to let history repeat itself. Consider the historical context of the 1948 Geneva Convention: the self-congratulatory triumphalism, the assurance that evil had been defeated, the bold pronouncements against genocide. All that came to naught in Rwanda.... Rwanda was simply too little, too far away, too poor, and too black for the "developed" world to care about. ${ }^{89}$

Finally, our responsibility to rebuild after intervention has still to be recognized. ${ }^{90}$ The criminal courts persevere with their work, more than a decade after the genocide; ${ }^{91}$ but, as Des Forges and Longman write,

Although stopping impunity and building the rule of law remain essential for Rwandan society to unity and avoid future violence, it remains unclear whether prosecutions as they are now being carried out will contribute to this process, or how they will do so. ${ }^{92}$

May enhances this viewpoint in his discussion of the real complexities of the international prosecution of genocide and the violation of State sovereignty. ${ }^{93}$

Nevertheless, we continue to look for the best ways to prevent mass atrocity, and to deal with it when it occurs. ${ }^{94}$ Yet the roots of conflict grow in the ongoing separation of Hutu and Tutsi, in government by a minority, and in the economic and social problems 
that remain. This does not augur well for a peaceful future. Will our laws and our commitment be ready for the next crisis?

\section{Notes}

1. Mark Freeman, "International Law and Internal Armed Conflicts: Clarifying the Interplay between Human Rights and Humanitarian Protections," Journal of Humanitarian Assistance (2000), http://www.jha.ac/articles/a059.htm (accessed 8 May 2007).

2. Fernando R. Teson, "The Liberal Case for Humanitarian Intervention," in Humanitarian Intervention: Ethical, Legal and Political Dilemmas, ed. J.L. Holzgrefe and Robert O. Keohane, 93-129 (Cambridge: Cambridge University Press, 2003), 129.

3. Freeman, "International Law."

4. International Committee of the Red Cross [ICRC], "International Humanitarian Law: Answers to Your Questions," http://www.icrc.org/Web/Eng/siteeng0.nsf/htmlall/ 5kzf5n?opendocument (accessed 30 May 2007).

5. Universal Declaration of Human Rights, UN General Assembly Resolution 217(III), UN Doc. A/810 (10 December 1948), http://www.unhchr.ch/udhr/lang/eng.htm (accessed 8 May 2007); Convention on the Prevention and Punishment of the Crime of Genocide, 9 December 1948, 78 U.N.T.S. 277, http://www.unhchr.ch/html/menu3/b/ p_genoci.htm (accessed 8 May 2007).

6. John N. Clarke, "A Pragmatic Approach to Humanitarian Intervention," Journal of Humanitarian Assistance (2001), www.jha.ac/articles/a146.pdf (accessed 8 May 2007).

7. Gareth Evans and Mohamed Sahnoun, The Responsibility To Protect: Report of the International Commission on Intervention and State Sovereignty (Ottawa: International Development Research Centre, 2001).

8. James Darcy, "Human Rights and Humanitarian Action: A Review of the Issues," background paper prepared for Human Rights and Humanitarian Action-Humanitarian Policy Group Background Paper (UNICEF Workshop, Geneva, 1-17 April 2004), http:// www.odi.org.uk/rights/Publications/HPGBackgroundPaperforIASC.pdf (accessed 8 May 2007).

9. Kirsten Zaat, "Legalising a Contemporary 'War of Peace': A Case for Humanitarian Intervention in the Sudan," Journal of Humanitarian Assistance (2004), www.jha.ac/ articles/a155.pdf (accessed 8 May 2007).

10. J.L. Holzgrefe, "The Context for Humanitarian Intervention," in Humanitarian Intervention: Ethical, Legal and Political Dilemmas, ed. J.L. Holzgrefe and Robert O. Keohane, 15-22 (Cambridge: Cambridge University Press, 2003).

11. Art 2(4) states that "All Members shall refrain in their international relations from the threat or use of force against the territorial integrity or political independence of any state, or in any other manner inconsistent with the Purposes of the United Nations"; art. 2(7) states that "Nothing contained in the present Charter shall authorize the United Nations to intervene in matters which are essentially within the domestic jurisdiction of any state or shall require the Members to submit such matters to settlement under the present Charter; but this principle shall not prejudice the application of enforcement measures under Chapter VII." Charter of the United Nations, 26 June 1945, ch. 1, http:/www.un.org/ aboutun/charter/chapter1.htm (accessed 8 May 2007).

12. Simon Chesterman, Just War or Just Peace: Humanitarian Intervention and International Law (Oxford: Oxford University Press, 2001); Holzgrefe, "Context for Humanitarian Intervention."

13. Evans and Sahnoun, Responsibility to Protect.

14. Tobias Vogel, "The Politics of Humanitarian Intervention," Journal of Humanitarian Assistance (2000), http://www.jha.ac/articles/a011.htm. Within internal armed conflict, the major sources of IHL protection include the following: (1) The Martens Clause, whereby parties involved in the armed conflict must act "in accordance with the principles of the law of nations derived from the usages established among civilized peoples, from the laws of 
humanity and the dictates of public conscience." M. Shaw, International Law, 5th ed. (Cambridge: Cambridge University Press, 2003), 1055. (2) Common art. 3, which states that those involved in internal armed conflicts must apply certain minimum standards to those not actively involved in hostilities, including a prohibition on violence, torture, and murder of all types; hostage taking; degrading and humiliating treatment; and executions without appropriate trial. (3) Protocol II, which enhances these by, inter alia, forbidding attacks or violent threats on civilians and forced civilian displacement. (4) Broader international human-rights legislation that supports all these, including conventions addressing genocide, torture, and refugees as well as legislation involved in crimes against humanity. (5) A variety of national, foreign and international judicial and quasi-judicial institutions that ostensibly serve to ensure the interpretation and enforcement of provisions. Freeman, "International Law."

15. Evans and Sahnoun, Responsibility to Protect, 36.

16. Ingvar Carlsson, Han Sung-Joo, and Rufus M. Kupolati, Report of the Independent Inquiry into the Actions of the United Nations during the 1994 Genocide in Rwanda, UN Doc. S/1999/1257 (1999), http://www.un.org/Docs/journal/asp/ws.asp?m=S/1999/1257 (accessed 8 May 2007); Statement of the Secretary-General on Receiving the Report of the Independent Inquiry into the Actions of the United Nations during the 1994 Genocide in Rwanda (16 December 1999), http://www.un.org/News/ossg/sgsm_rwanda.htm (accessed 8 May 2007); Interim Report of the Commission of Experts established in accordance with Security Council Resolution 935, UN Doc. S/1994/1125 (4 October 1994).

17. Michael A. Innes, "The New Banality, Modern Atrocities, and the Future of Humanitarian Intervention," Journal of Humanitarian Assistance (2002), http://www.jha.ac/articles/ a083.htm (accessed 8 May 2007).

18. Clarke, "Pragmatic Approach."

19. Joakim Dungel, "A Right to Humanitarian Assistance in Internal Armed Conflicts Respecting Sovereignty, Neutrality and Legitimacy: Practical Proposals to Practical Problems," Journal of Humanitarian Assistance (2004), http://www.jha.ac/articles/ a133.htm (accessed 8 May 2007).

20. Arthur Klinghoffer, The International Dimension of Genocide in Rwanda (New York: New York University Press, 1998); Thomas Pogge, "Preempting Humanitarian Interventions," in Humanitarian Intervention: Moral and Philosophical Issues, ed. Aleksandar Jokic, 93-108 (Peterborough, ON: Broadview Press, 2003).

21. E.g., Oliver Ramsbotham and Tom Woodhouse, Humanitarian Intervention in Contemporary Conflict (Cambridge: Polity Press, 1996).

22. Hugo Slim, "Military Intervention to Protect Human Rights: The Humanitarian Agency Perspective," Journal of Humanitarian Assistance (2002), http://www.jha.ac/articles/ a084.htm (accessed 8 May 2007).

23. Slim, ibid.; Klinghoffer, International Dimension. Jane Stromseth, "Rethinking Humanitarian Intervention: The Case for Incremental Change," in Humanitarian Intervention: Ethical, Legal and Political Dilemmas, ed. J.L. Holzgrefe and Robert O. Keohane, 232-72 (Cambridge: Cambridge University Press, 2003), 7-8, provides a useful outline of differing approaches to such intervention, claiming that the current situation lies between 2 and 3: "(1) the status quo approach, denying the legitimacy of unauthorized intervention; (2) the 'excusable breach' approach; (3) a 'customary law evolution of a legal justification' approach; and (4) an approach advocating a clear right of humanitarian intervention."

24. Shaw, International Law; Dungel, "Right to Humanitarian Assistance."

25. For a detailed chronology demonstrating ongoing problems with IHL/IHRL, see Christian P. Scherrer, Genocide and Crisis in Central Africa: Conflict Roots, Mass Violence, and Regional War (London: Praeger, 2002), 96-99, 342-43.

26. Klinghoffer, International Dimension; Alison Des Forges, Leave None to Tell the Story: Genocide in Rwanda (New York: International Federation of Human Rights, 1999); Alison Des Forges, "Ten Lessons to Prevent Genocide," http://www.peace.ca/ 
ten_lessons_to_prevent_genocide_htm (accessed 30 May 2007); Jean Chretien, The Great Lakes of Africa, trans. Scott Strauss (New York: Zone Books, 2003).

27. Following fighting in 1990 between the Tutsi-led Rwandan Patriotic Front (RPF) and the mostly Hutu government of Rwanda, a ceasefire agreement was brokered by Tanzania and the Organization of African Unity (OAU) on 22 July 1992 at Arusha in the United Republic of Tanzania. Reconvening in March 1993, after hostilities had interrupted the negotiations, the two sides finalized a peace agreement in August 1993 to end the civil war. This agreement included the move to a democratically elected government, with a broad-based transitional government until the elections, as well as refugee repatriation and integration of the armed forces of both sides. UNAMIR was to ensure implementation and monitoring from October 1993 and support the new transitional government. "United Nations Observer Mission Uganda-Rwanda" (backgrounder, UN Department of Peacekeeping Operations, n.d.), http://www.un.org/Depts/dpko/dpko/co_mission/unomurbackgr.html (accessed 9 May 2007) [UNOMUR Backgrounder].

28. Mahmood Mamdani, When Victims Become Killers (Princeton, NJ: Princeton University Press, 2001); Scherrer, Genocide and Crisis. According to these authors, there are numerous explanations for such civilian involvement, apparently the first in history on such a massive scale, in the genocide: economic, in terms of resources; cultural, in terms of mindset, racism, and obedience to authority; and political, in terms of power-a reversal of the 1959-1963 civil war, in which the Hutu came to power, and fear of a return to Tutsi-dominated Rwanda igniting the 1990-1994 war and genocide.

29. Bacre Waly Ndiaye, Question of the Violation of Human Rights and Fundamental Freedoms in Any Part of the World, with Particular Reference to Colonial and other Dependent Countries and Territories: Extrajudicial, Summary or Arbitrary Executions, UN Doc. E/CN.4/1998/68/Add.2 (11 August 1993), http://www.sangam.org/FB_REPORTS/ Index98Rapp.htm (accessed 30 May 2007).

30. Klinghoffer, International Dimension; Adam LeBor, "Complicity with Evil": The United Nations in the Age of Modern Genocide (New Haven, CT: Yale University Press, 2006).

31. Scherrer, Genocide and Crisis. Existing racism was enforced through an extreme propaganda campaign leading up to the 1994 genocide. However, the genocide itself was also a retributive one, rooted in fear of renewed Tutsi domination, as symbolized by the $\mathrm{RPF}$, and fuelled by racist propaganda in the media. The Tutsi killing of 200,000 Hutu in Burundi in 1972 had not been forgotten. Unfortunately, a historical reading demonstrates ethnic discrimination on both sides, but in 1994 the additional crucial aspect of the situation was a perception of threat and a return to Hutu servitude under the RPF. René Lemarchand, "Disconnecting the Threads: Rwanda and the Holocaust Reconsidered," Idea: A Journal of Social Issues 7 (2001), http://www.ideajournal.com/genocide-2001lemarchand.html (accessed 9 May 2007).

32. John N. Clarke, "Early Warning Analysis for Humanitarian Preparedness and Conflict Prevention," Journal of Humanitarian Assistance (2004), www.jha.ac/articles/a146.pdf (accessed 9 May 2007), provides a useful template for analyzing early warning signals for humanitarian preparedness and for preventing conflict, emphasizing the need to understand a humanitarian crisis in the context of social, political, and economic variables. Key factors to consider are socioeconomic conditions; state and institutions; the regional/ international dimension; security; public discourse, ideological factors, and elite behavior; human rights and civil liberties; and actors. According to Clarke's argument, the Rwandan disaster was badly managed in terms of preparedness and preventive measures because the structural and proximate indicators were ignored, and, given the triggering event, failure to deal adequately with the ensuing conflict situation was more likely. He cites Rwandan examples such as the mobilization of groups for violent action through political speeches and media propaganda.

33. Bruce Jones, "Intervention without Borders: Humanitarian Intervention in Rwanda 1990-1994," Millenium 24 (1995), cited in Klinghoffer, International Dimension, 33. One example will suffice. While there was torture and murder of men, women, and 
children, it is important to note that (as is now the case in Darfur) 500,000 women and girls were sexually tortured and murdered during the genocide, and rape survivors were left to a social death after the war, ostracized from their communities, many left with children born of the horror, and infected with HIV. Llezlie Green, "Propaganda and Sexual Violence in the Rwandan Genocide: An Argument for Intersectionality in International Law," Columbia Human Rights Law Review 33 (2002): 733-76; H. Patricia Hynes, "On the Battlefield of Women's Bodies: An Overview of the Harm of War to Women," Women's Studies International Forum 27 (2004): 431-45. As indicated earlier, the UN Security Council, in October 1993, established an international force, UNAMIR, to support the Arusha peace agreement; in June 1993 the Security Council had authorized the United Nations Observer Mission Uganda-Rwanda (UNOMUR) to prevent military moves by the RPF and military assistance to Rwanda [UNOMUR Backgrounder]. Operation Turquoise, authorized by the Security Council in June 1994, was a French-led mission to establish a 'safe humanitarian zone' in the southwest of Rwanda. William Schabas, Genocide in International Law: The Crime of Crimes (Cambridge: Cambridge University Press, 2000).

34. Klinghoffer, International Dimension; Mamdani, When Victims Become Killers; Slim, "Military Intervention."

35. Carlsson et al., Report of the Independent Inquiry, 30.

36. When the world declared after the Rwandan genocide that it should never happen again, history presented us with Srebrenica in 1995 and with Darfur, currently our next Rwanda, with the same long period for recognition of genocide and consequent inadequate action. Romeo Dallaire, former commander of UNAMIR forces in Rwanda, calls it "looking at Darfur, seeing Rwanda." Romeo Dallaire, "Looking at Darfur, Seeing Rwanda," New York Times, 4 October 2004, http://www.ksg.harvard.edu/news/opeds/2004/ Dallaire_looking_darfur_seeing_rwanda_nyt_100404.htm (accessed 10 May 2007). He notes failures to take note of early warnings evident since 2001, quibbles over definitions, a lack of safety in refugee camps, and the failure of the UN to prevent the ongoing crisis, although he admits that there has been a useful humanitarian operation in Darfur. Adam LeBor believes that the UN has actually been complicit with evil in the case of Rwanda, Screbrenica, and Darfur: "Despite everything the United Nations knew about its failures in Rwanda ... in Darfur the United Nations had failed on every one of Annan's five points: the armed conflict had not been prevented; civilians had not been protected; Khartoum still acted with impunity; and in spite of a year's worth of warnings ... about sustained human rights abuses, no 'swift and decisive action' was taken to prevent genocide, although the United Nations' extensive humanitarian operation had saved many lives.... [The State Department's report on Darfur claimed that] it... was the worst human rights crisis in the world [and] ... showed that the Sudanese government had carried out one of the largest ethnic-cleansing operations of Muslims in modern times.... If the United Nations cannot prevent genocide, its legal organs have at least clarified for the modern world what genocide is. Srebrenica, Rwanda, and Darfur are now linked by a steadily evolving corpus of humanitarian law that transcends national boundaries." LeBor, Complicity with Evil, $172,196,219$.

37. Klinghoffer, International Dimension, 5.

38. Christopher Taylor, Sacrifice as Terror: The Rwandan Genocide of 1994 (Oxford: Berg, 1999); Chesterman, Just War or Just Peace; Emmanuel Bensah, "The Rwandan Genocide 10 Years Later," ZNet Activism (2004), http://www.zmag.org/content/ print_article.cfm?itemlD=1 (accessed 20 May 2005); David Scheffer, "Lessons from the Rwandan Genocide," Georgetown Journal of International Affairs (2004): 125-32; Vogel, "Politics of Humanitarian Intervention"; Carlsson et al., Report of the Independent Inquiry; Innes, "New Banality"; Evans and Sahnoun, Responsibility to Protect; Lemarchand, "Disconnecting the Threads"; Shedrack C. Agbakwa, "Genocidal Politics and Racialization of Intervention: From Rwanda to Darfur and Beyond," German Law Journal 6 (2005): 513-31, http://www.germanlawjournal.com/article.php?id=573 (accessed 10 May 2007); D.R.L. Ludlow, "Humanitarian Intervention and the Rwandan Genocide," 
Journal of Conflict Studies (1999), http://www.lib.unb.ca/Texts/JCS/spring99/ludlow.htm (accessed 30 May 2007).

39. An example is the UN intervention in Somalia's civil war, where humanitarian aid served to inflame the war by leading warlords to fight over valuable goods. Holzgrefe, "Context for Humanitarian Intervention."

40. Klinghoffer, International Dimension.

41. Christine Gray, International Law and the Use of Force, 2nd ed. (Oxford: Oxford University Press, 2004). Reports on clear breaches of law were ignored from 1993 onwards, such as that of Bacre Ndiaye, who in April 1993 visited Rwanda and reported the occurrence of massacres and human-rights violations, including the possibility of genocide against the Tutsis. His report was published a week after the Arusha Peace Agreement was signed on 4 August 1993. Other unheeded warnings came from UNAMIR Commander Dallaire: he received no formal response to his request (23 November 1993) to allow the mission to act and use force in confronting crimes against humanity, and his telegram of 11 January 1994, citing the planning for genocide, was virtually ignored. Even when the special Security Council representative, Jacques-Roger Booh-Booh, warned of the deterioration of the security situation in a cable of 2 February 1994, no humanitarian response was forthcoming. Instead we find a lack of care in repatriating foreign nationals, downgrading of troop numbers, and a continuation of rhetoric instead of action, stemming from fear that any action taken might lead to a need to use force and to other unknown consequences.

It seems that both the United States and the UN wanted to resist the term "genocide," only belatedly (on 8 June 1994) accepting the notion of "acts of genocide," as the former might have committed them to action. Amazingly, too, the situation was worsened by the ongoing presence of Rwanda as a member of the Security Council during the genocide. Klinghoffer, International Dimension; Carlsson et al., Report of the Independent Inquiry; Mamdani, When Victims Become Killers.

42. Carlsson et al., Report of the Independent Inquiry. But, as a reviewer of this manuscript reminds us, "The vote to reduce UNAMIR forces was agreed by all states on the Security Council because the troops to be evacuated were hardly trained or equipped and were a drain on remaining resources. The fault... was the failure to reinforce the residual force with equipped and adequately trained troops. The Security Council's decision to mandate more troops in May was not more 'appropriate'- the Council members knew that no troops could go as there was no air-lift offered."

43. Ibid.

44. Gray, International Law.

45. Carlsson et al., Report of the Independent Inquiry.

46. Ibid; Mamdani, When Victims Become Killers; Scherrer, Genocide and Crisis.

47. Scherrer, ibid.; Geoffrey Robertson, Crimes against Humanity: The Struggle for Global Justice (London: Allen Lane, 1999).

48. The outcome is well summarized as follows: "Nothing has done more harm to our shared ideal that we are all equal in worth and dignity, and that the earth is our common home, than the inability of the community of states to prevent genocide, massacre and ethnic cleansing. If we believe that all human beings are equally entitled to be protected from acts that shock the conscience of us all, then we must match rhetoric with reality, principle with practice. We cannot be content with reports and declarations. We must be prepared to act. We won't be able to live with ourselves if we do not." Evans and Sahnoun, Responsibility to Protect, 75.

49. Ludlow, "Humanitarian Intervention."

50. Enormous amounts of time and energy seemed to have been expended in Washington by those concerned more with policy issues and the legal implications of adopting the term than with the reality of the situation. Two examples suffice: a legal opinion emphasizing that accepting the term would necessarily mean action; and the reports of a June 1994 press-conference debate over the differences between admitting "acts of genocide," 
which was what the State Department had accepted, and calling the situation "genocide" per se, which China refused to accept. Innes, "New Banality."

51. Ibid.

52. Schabas, Genocide in International Law, 12, 546.

53. Scheffer, "Lessons from the Rwandan Genocide."

54. Schabas, Genocide in International Law.

55. Carlsson et al., Report of the Independent Inquiry, 27.

56. Evans and Shanoun, Responsibility to Protect, 73.

57. Michael Ignatieff, "State Failure and Nation-Building," in Humanitarian Intervention: Ethical, Legal and Political Dilemmas, ed. J.L. Holzgrefe and Robert O. Keohane, 299-321 (Cambridge: Cambridge University Press, 2003), 316.

58. Chesterman, Just War or Just Peace.

59. Allen Buchanan, "Reforming the International Law of Humanitarian Intervention," in Humanitarian Intervention: Ethical, Legal and Political Dilemmas, ed. J.L. Holzgrefe and Robert O. Keohane, 130-73 (Cambridge: Cambridge University Press, 2003), 131.

60. Ibid.

61. Vogel, "Politics of Humanitarian Intervention."

62. Innes, "New Banality."

63. Carlsson et al., Report of the Independent Inquiry.

64. Clarke, "Pragmatic Approach."

65. Ishbel Matheson, "First Rwanda, Then Darfur, and Next? How We Can Help to End These Horrors," The Times, 16 October 2006, http://www.timesonline.co.uk/tol/comment/columnists/guest_contributors/article601484.ece (accessed 10 May 2007).

66. Robertson, Crimes against Humanity.

67. Jane Stromseth, "Introduction: Goals and Challenges in the Pursuit of Accountability," in Accountability for Atrocities: National and International Responses, ed. Jane Stromseth, 1-38 (New York: Transnational Publishers), 9.

68. Alison Des Forges and Timothy Longman, "Legal Responses to Genocide in Rwanda," in $M y$ Neighbor, My Enemy: Justice and Community in the Aftermath of Mass Atrocity, ed. Eric Stover and Harvey Weinstein, 49-68 (Cambridge: Cambridge University Press, 2004), 49.

69. Anne Ryniker, "The ICRC's Position on 'Humanitarian Intervention," International Review of the Red Cross 83 (2001): 527-32, 527.

70. Thomas Franck, "Interpretation and Change in the Law of Humanitarian Intervention," in Humanitarian Intervention: Ethical, Legal and Political Dilemmas, ed. J.L. Holzgrefe and Robert O. Keohane, 204-31 (Cambridge: Cambridge University Press, 2003).

71. Clarke, "Pragmatic Approach."

72. Evans and Sahnoun, Responsibility to Protect, 69.

73. K. Mills, "Sovereignty Eclipsed? The Legitimacy of Humanitarian Access and Intervention," Journal of Humanitarian Assistance (1997), http://www.jha.ac/articles/ a019.htm (accessed 10 May 2007).

74. Human Rights Watch [HRW], “Ten Years Later" (2004), http://www.hrw.org/reports/1999/ rwanda/10years.htm (accessed 10 May 2007).

75. "Juan E. Méndez," in Wikipedia, http://en.wikipedia.org/wiki/Juan_E._M\%C3\%A9ndez (accessed 10 May 2007).

76. BBC News, 16 April 2005, http://news.bbc.co.uk/2/hi/americas/445094.stm (accessed 20 May 2005).

77. In relation to Darfur, as Schabas puts it, "it would be better to engage States in a commitment to intervene, with force if necessary, in order to prevent the crime of genocide, rather than to expand the definition or suggest its borders are uncertain." Genocides in International Law, 552. However, the fact that, three years after the Sudanese government had begun to engage in genocide in Darfur, not even a peacekeeping force had been deployed by the UN suggests an ongoing failure of prevention. LeBor, Complicity with Evil. 
78. Stromseth, "Rethinking Humanitarian Intervention."

79. Burleigh Wilkins, "Humanitarian Intervention: Some Doubts," in Humanitarian Intervention: Moral and Philosophical Issues, ed. Aleksandar Jokic, 35-44 (Peterborough, ON: Broadview Press, 2003).

80. Anand Panyarachun, United Nations Report: A More Secure World-Our Shared Responsibility (New York: United Nations, 2004), 57.

81. Chesterman, Just War or Just Peace; Taylor, Sacrifice as Terror; Scherrer, Genocide and Crisis; Daniel Muñoz-Rojas and Jean-Jacques Frésard, "The Roots of Behaviour in War: Understanding and Preventing IHL Violations," International Review of the Red Cross 86 (2004): 190-205.

82. Des Forges and Longman, "Legal Responses," 51.

83. Slim, "Military Intervention."

84. Agbakwa, "Genocidal Politics."

85. Steven R. Weisman, "Powell Declares Genocide in Sudan in a Bid to Raise Pressure," New York Times, 9 September 2004 (late ed.), A3.

86. Interpreting such behavior, we find that "indifference and selective intervention carries the scars of a limited moral imagination, the guilty indulgence of a voyeuristic perversion: the Other may perish, if it is not in our interest to help." Innes, "New Banality," 10.

87. Quoted in Carlsson et al., Report of the Independent Inquiry, 2.

88. Peter Beinart, "How To Save Darfur," Time, 2 October 2006, 35.

89. Taylor, Sacrifice as Terror, 182.

90. Evans and Sahnoun, Responsibility to Protect; HRW, "Ten Years Later."

91. Olivier Dubois, "Rwanda's National Criminal Courts and the International Tribunal," International Review of the Red Cross 321 (1997): 717-31, http://www.icrc.org/Web/eng/ siteeng0.nsf/html/57JNZA (accessed 10 May 2007).

92. Des Forges and Longman, "Legal Responses," 49.

93. Larry May, Crimes Against Humanity. A Normative Account (Cambridge: Cambridge University Press, 2005).

94. Mark Osiel, "The Banality of Good: Aligning Incentives against Mass Atrocity," Columbia Law Review 105 (2005): 1751-863. 